\title{
Meat Breed-Palas, A Creation of Romanian Scientific Research, in the Field of Sheep Breeding
}

\author{
G.P. Vicovan ${ }^{1}$, Ana Enciu ${ }^{2}$, Cristina Stefania Pirvulet ${ }^{3}$, R. Radu ${ }^{4}$ \\ ${ }^{1,2,4}$ Research and Development Institute for Sheep and Goats Breeding-Palas I.C. Bratianu Street 248, Constanţa, România \\ ${ }^{3}$ The Academy of Agricultural and Forestry Sciences - Section of Animal Husbandry
}

\begin{abstract}
The Meat Breed of Palas was created during 1973-2012 at Central Research Station for Sheep Breeding Palas- Constanta (nowadays the Research and Development Institute for Sheep and Goats Breeding- Palas) by crossbreeding of the breeds Ile de France and Merino of Palas followed by reproductive isolation starting with 1989. The breed was recognized and homologated in 2012.By its traits, the breed is clearly different from the local sheep breeds of Merino of Palas, Tzigaia and Tzurcana. So, the body weights of ewes and rams are bigger with 7,54-8,55\% than the body weight of the same categories from Merino of Palas breed, the differences being very significant ( $1<0,001)$. Also, the lambs from this breed have a daily gain which is bigger with 16,84-43,01\% besides the lambs of local sheep breeds. The slaughtering output at the fattened young rams of the Meat Breed of Palas is bigger with 3, 75-5, 15 per cent points besides their contemporaries from the local sheep breeds. Also, the carcasses of lambs from the Meat Breed of Palas are larger, more compact, having shorter gigots, well covered with muscles comparatively to the contemporaries of local sheep breeds. The surfaces of the sections of Longissimus Dorsi muscle and of the tigh are bigger with 17,14-47,30\% respectively with 26,43-41,92\% at the Meat Breed of Palas comparatively to the local sheep breeds, fact that reveals a good development of muscles in the area of the back, of the loins and of the gigot. All the carcasses of the lambs from the Meat Breed of Palas are categorized in the U class (very good carcasses) by conformation but after the fattening state are categorized in the 2-3 classes (thin carcasses and mild fat required on the market). At Merino of Palas approximately half of the carcasses are in class $R$ (good carcasses) and half in $O$ class (satisfactory). At Tzigaia breed, the carcasses are of $O$ class, but at Tzurcana $20 \%$ of carcasses are in $O$ class $O$ and $80 \%$ in $P$ class (mediocre carcasses). In conclusion it could be said that the Meat Breed of Palas (the only local breed of this type in Romania) has a body format and morphproductive features similar to other meat breeds that are being bred in the European Union's countries with tradition.
\end{abstract}

Keywords: Meat Breed- Palas, gigot, crossbreeding.

\section{Introduction}

In 1970-1971 at Central Research Station for Sheep Breeding Palas- Constanţa, following the researches regarding the potential for the meat production of the local sheep breeds (Merino, Tzigaia, Tzurcana) resulted that they achieve at fattening poor weigh increasing rates comparatively to the meat breeds from West Europe ( see Ciolcă and colab. [1]). Also, at the local sheep breeds the slaughtering output and the quality indicators of the carcasses had much inferior values than the breeds that are specialized for the meat production. From the local sheep breeds only Merino of Palas had higher values for the main determining features of the meat production, but they were under the limit of the meat breeds.

To improve the meat production at the breed of Merino of Palas, the solution of that time was that of crossbreeding, to create a new breed, specialized for meet. On the basis of available data regarding the productive potential of the meat breeds from West Europe, Ile de France breed was chosen, breed that presented high values at the main morph productive indicators on which the meat production depended.

So, in 1972 a nucleus of 30 sheep from Ile de France breed was imported from France and was brought to the Central Research Station for Sheep Breeding Palas- Constanţa, to be used at crossbreeding with Merino of Palas.

\section{Material and Method}

The breed resulted as a result of doing some researches at SCCCO Palas- Constanţa since 1970 regarding the establishment of the potential for the meat production at Merino of Palas breed and the possibilities of improving it by selection and/or crossbreeding with specialized breeds.

The researches revealed the fact that Merino of Palas (photo 1,2 ) even it had a satisfactory speed of growing, it did not have a body conformation to let producing quality carcasses, well covered with muscles, with a meat/bones proportion close to the meat breeds and neither a superior slaughtering output similar to the meat breeds.

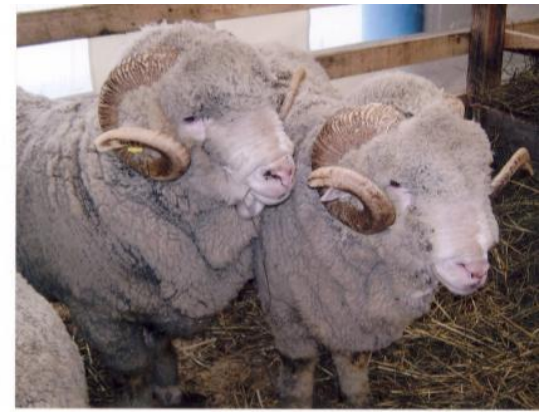

Photo 1: Rams of Palas Merino breed 


\section{International Journal of Science and Research (IJSR) \\ ISSN (Online): 2319-7064}

Index Copernicus Value (2013): 6.14 | Impact Factor (2014): 5.611

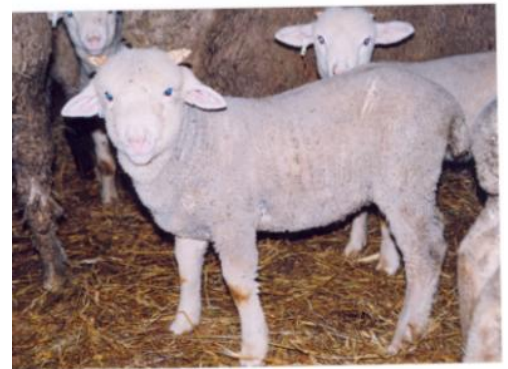

Photo 2: Lamb of Palas Merino breed

Due to the relatively big number of features on which the meat production depends, to the difficulties in appreciation of sheep and their carcasses' conformation, on those times not being an European grid of classification, and also the small to middle values for the heritability coefficients, the improvement of such features through selection would have needed a long time (cca.50-60 years) with high expenses (due to the need to watch big effectives of sheep on which the performances should have registered individually).

The good results obtained by crossbreeding, regarding the performances of the F1 Ile de France x Merino of Palas, allowed to continue the researches of producing and studying F2, F3, F4 and R1 between the breeds of Ile de France and Merino of Palas, under the aspect of the main features on which the meat production depended. In parallel there were studied also the performances of other complex half-bred sheep obtained from mating of the rams of Ile de France and Suffolk with half-bred ewes with high prolificacy (F1 Romanov x Merino, F1 Ostfrise x Merino and other types).

Due to the good results obtained by these half-bred especially regarding the prolificacy, a small number of females obtained from these mating were kept for reproduction besides the sheep of F1, F2, F3 and R1 Ile de France x Merino of Palas. The above presented half-bred series were being made and tested on the aspect of their aptitudes for the meat production between 1973 and 1980 .

During 1981-1988 it was proceeded to mating of the rams which had had in their genome $62,5 \%$ genes from the breed of Ile de France, $25 \%$ genes from Merino of Palas and 12,5\% genes from the prolific breeds and Suffolk with half-bred ewes from F3 and F4 generations (50\% Ile de France, 50\% Merino) obtaining more generations of products from the ", desired type", they having theoretically the genome made of $56,25 \%$ genes from Ile de France breed, 37,50\% genes from the Merino of Palas and 6,25\% genes from other breeds (especially from Romanov, Ostfrise and Suffolk breeds).

The rams and ewes from the „, desired type" had their conformation close to the breed of Ile de France, high speed of growing, good slaughtering output and carcasses of superior quality.

Since 1989 the population of half-breed sheep from the "desired type" was reproductively isolated and selected to increase in improve the meat production.
The Meat Breed - Palas was accepted as new sheep breed and homologated in 2012 (see photo3, 4 and 5).

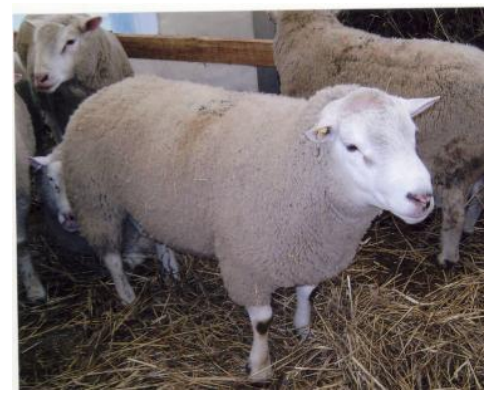

Photo 3: Ram of Meat Breed Palas

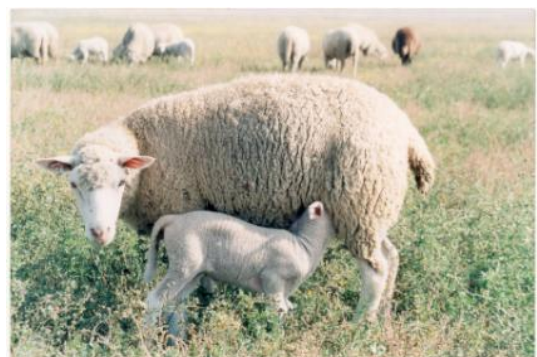

Photo 4: Ewe and lamb of Meat Breed Palas

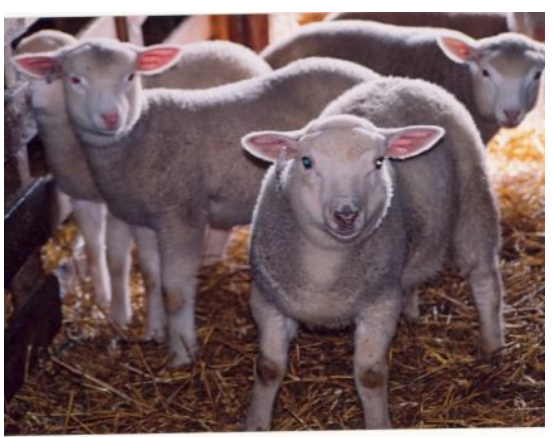

Photo 5: Lambs of Meat Breed Palas

- The genetic size of the breed $(\mathrm{Ne})$

Is given by the formula (1):

$$
\mathrm{N}_{\mathrm{e}}=\frac{4 \mathrm{~N}_{\mathrm{m}} \times \mathrm{N}_{\mathrm{f}}}{\mathrm{N}_{\mathrm{m}}+\mathrm{N}_{\mathrm{f}}}
$$

where:

$\mathrm{N}_{\mathrm{e}}$ - effective size (genetically)

$\mathrm{M}_{\mathrm{m}}$ - number of active males at reproduction

$\mathrm{N}_{\mathrm{f}}-$ number of females

- The degree of reproductive isolation

The degree of isolation is the fundamental criterion to considerate a population as a breed.

The coefficient of reproductive isolation is determined according to the formula (2):

$$
C I R=\frac{\mathrm{A} A-(A I+I I)}{A A+A I+I I}
$$

Where:

$\mathrm{AA}=$ number of individuals that are admitted to reproduction with both parents from own breeding.

$\mathrm{AI}=$ number of individuals with an immigrant parent.

$\mathrm{II}=$ number of individuals with both immigrant parents. 


\section{International Journal of Science and Research (IJSR) \\ ISSN (Online): 2319-7064}

Index Copernicus Value (2013): 6.14 | Impact Factor (2014): 5.611

The value of CIR varies between -1 and +1 passing through 0 (zero).

When the value of CIR varies between -1 and 0 then the sheep population cannot be considered as a breed. It is considered breed a population which had CIR with values between 0 and +1 more exactly between $+0,8$ and +1 for 5 generations (after Drăgănescu C.[2]).

- The slaughtering output was determined according to the formulae $(3,4)$

$$
\begin{aligned}
& \text { Output } 1=\frac{\text { Cooled carcas sweight }}{\text { Living weight }} \times 100 \\
& \text { Output } 2=\frac{\text { Cooled carcas sweight }}{\text { Empty living weight }} \times 100
\end{aligned}
$$

Empty living weight $=$ living weight - content of digestive tube (pre-stomachs, glandular stomach, intestines).

- Indicators of carcass $(5,6)$

$$
\begin{aligned}
& I C=\frac{G}{K} \times 100 \\
& I J=\frac{G}{F} \times 100
\end{aligned}
$$

Note:

IC $=$ indicator of carcass compactness

$\mathrm{IJ}=$ indicator of gigot compactness (after the formula of Purchas, quoted by [3]).

$\mathrm{G}=$ width at the cox-femoral articulations, measured with the compass.

$\mathrm{K}=$ length of carcass, measured with the ribbon on the back between the articulation of neck with the body (V7 neck with V1 thorax) and base of tail (sacrum-caudal art.).

$\mathrm{F}=$ length of gigot measured with the ribbon on the internal part of the mutton's leg between ischium -pubis and tarsemetatarsal articulation (in the middle).

- Surfaces of sections

The surfaces (areas) of the section of Longissimus Dorsi muscle between the $12^{\text {th }}$ and the $13^{\text {th }}$ rib and the surface of the thigh's section perpendicular to the femur axe at its middle were measured. Determination of surfaces was done on computer through Auto CAD programme.

\section{Results and Discussions}

\subsection{Reproductive isolation of the Meat Breed- Palas}

In table 1 it is presented the evolution of the reproductive isolation at the Meat Breed - Palas during 1973-2015.

Table1: Evolution of the reproductive isolation coefficient (CIR) at the Meat Breed - Palas

\begin{tabular}{|c|c|c|c|c|c|c|c|c|c|}
\hline \multirow{2}{*}{ Specification } & \multicolumn{10}{|c|}{ Years } \\
\cline { 2 - 10 } & 1973 & 1976 & 1981 & 1989 & 1994 & 1999 & 2003 & 2009 & 2015 \\
\hline CIR Values & -1 & $+0,54$ & $+0,81$ & +1 & $+0,94$ & $+0,98$ & +1 & +1 & +1 \\
\hline
\end{tabular}

From the data in the table resulted during 1973-1981 the reproductive isolation of the Meat Breed - Palas was relative, the coefficient of reproductive isolation evaluating from the value of -1 in 1973 when the first F1 half-bred sheep with both immigrant parents were produced) at the value of $+0,81$ in 1981 when only certain individuals from the population had one immigrant parent each. Since 1989 until present the reproductive isolation was total, CIR having the value of +1 or very close to it $(+0,94$ in 1994 and $+0,98$ in 1999).

\subsection{The genetic similarity of the Meat Breed of Palas with the founding breeds}

It is presented in table 2 .

Table 2 Evolution of genetic similarity of the Meat Breed of Palas with the founding breeds during 1989-2012

\begin{tabular}{|c|c|c|c|c|c|c|c|}
\hline \multirow{2}{*}{ No } & \multirow{2}{*}{ Breed } & \multicolumn{6}{|c|}{ Rxy (\%) of ewes born on year..... with breed } \\
\cline { 3 - 8 } & 1989 & 1994 & 1999 & 2003 & 2009 & 2012 \\
\hline 1. & Ile de France & 55,67 & 58,45 & 53,29 & 56,67 & 56,78 & 56,80 \\
\hline 2. & $\begin{array}{c}\text { Merino of } \\
\text { Palas }\end{array}$ & 41,25 & 40,15 & 39,71 & 34,10 & 36,28 & 36,30 \\
\hline 3. & $\begin{array}{c}\text { Other } \\
\text { breeds* }\end{array}$ & 3,03 & 1,39 & 6,98 & 9,19 & 6,90 & 6,90 \\
\hline
\end{tabular}

* Other breeds: Romanov, Ostfrise, Suffolk.

From data presented in table 2 results that in 1989 (when the „desired type" for the Meat Breed of Palas was established) the genetic similarity with Ile de France breed was of $55,67 \%$, then, in the evolution of the next generations it oscillated between the values of 58,45\% in 1994 and 53,29\% in 1999 and after that it has been stabilized round the value of $57 \%(56,67 \%$ in 2003 and $56,80 \%$ in 2012).

The similarity of the Meat Breed of Palas with Merino of Palas was of $41,25 \%$ in 1989 and progressively decreased during all the analysed periods, reaching the value of $36 \%$ $(36,28 \%)$ in 2009 .

From the same table it can be noticed that at forming the Meat Breed of Palas other breeds of smaller importance contributed, the similarity with them growing from the value of $3,03 \%$ in 1989 to $6,90 \%$ in 2012 .

In the category of other breeds were included: Suffolk to which the Meat Breed is similar in proportion of $3,66 \%$ in 2012; Romanov to which it is similar in proportion of $2,36 \%$ and Ostfrise to which it is similar in proportion of $0,88 \%$.

After 2012 Meat Breed of Palas did not modify its genetic structure, remaining reproductively isolated and being genetically stabile.

\subsection{Evolution of the interval between generations}

The evolution of the interval between generations in the analysed period of 1989-2009 is presented in table 3 .

\section{Volume 5 Issue 6, June 2016 www.ijsr.net}




\section{International Journal of Science and Research (IJSR) \\ ISSN (Online): 2319-7064}

Index Copernicus Value (2013): 6.14 | Impact Factor (2014): 5.611

Table 3: The evolution of the interval between generations during 1989-2009

\begin{tabular}{|c|c|c|c|c|c|}
\hline \multirow{2}{*}{ Year } & \multicolumn{5}{|c|}{ Interval in years } \\
\cline { 2 - 6 } & $\begin{array}{c}\text { Father- } \\
\text { son }\end{array}$ & $\begin{array}{c}\text { Father - } \\
\text { daughter }\end{array}$ & $\begin{array}{c}\text { Mother- } \\
\text { son }\end{array}$ & $\begin{array}{c}\text { Mother - } \\
\text { daughter }\end{array}$ & Average \\
\hline 1989 & 3,31 & 3,19 & 4,51 & 4,30 & 3,77 \\
\hline 1994 & 4,10 & 4,01 & 3,75 & 3,46 & 3,83 \\
\hline 1999 & 2,60 & 2,49 & 4,65 & 4,83 & 3,33 \\
\hline 2003 & 2,85 & 2,81 & 4,40 & 4,70 & 3,53 \\
\hline 2009 & 3,32 & 3,12 & 3,44 & 4,63 & 3,78 \\
\hline $\begin{array}{c}\text { Average } \\
1989-2009\end{array}$ & 3,24 & 3,12 & 4,15 & 4,38 & 3,65 \\
\hline
\end{tabular}

It is observed that on the total period of 1989-2009 the average interval on the lines of father-son and fatherdaughter was 3,24 years, respectively 3,12 years, smaller than on the lines of mother-son and mother-daughter which was of 4,15 and respectively 4,38 years.

Per total of analysed period and total of birth lines the average interval between generations at the Meat Breed of Palas was of $\mathbf{3 , 6 5}$ years.

\subsection{The genetic size of the breed $(\mathrm{Ne})$}

In 2009 the genetic size of the Meat Breed of Palas was of 93,11 individuals.

\subsection{Morphological characters}

\subsubsection{Conformation of body}

- It is specific to the sheep of meat breeds.

- The head is long and wide enough, with the face profile straight or fairly convex at ram, the ears are big enough, worn horizontally or fairly raised, the neck is short, well connected to trunk, without tie and necklace.

- The trunk is long and wide, of cylindrical shape.

- The chest is large, the ribs are fairly arched, the thorax is wide and deep, the back and the loins are long and wide, well covered with muscles.

- The rump is large and long enough, horizontal or fairly oblique.

- The gigot have convex profile.

- The legs are long enough, with fine bones and correct aplomb.

- The udder is globe-shaped, symmetrical, mean size.

- The wool cover is white, dresses well the body, the wool being extended from the head until the level of orbits and on legs till the knees. The tail is covered with wool.

- The face, ears and legs are covered with hair of white colour.

- Both sexes do not have horns, their presence being considered eliminatory defect from reproduction.

- The black colour of wool, hair or black spots on the body is not accepted.

- There are accepted coloured of small dimensions, on mouth, eyelids, perineum and vulva.

The body dimensions:

- The stature is mean to big.

\section{At rams:}

- Height at withers: 69-71 cm;

- Height at rump: 69-71 cm;

- Length of body: 73-75 cm;

- Length of rump: $26-28 \mathrm{~cm}$;

- Width at shoulders: $27-28 \mathrm{~cm}$;

- Width at cox-femoral articulations: $29-31 \mathrm{~cm}$;

- Depth of thorax: 33-35 cm;

- Width of thorax: $31-33 \mathrm{~cm}$;

- Perimeter of thorax: $97-99 \mathrm{~cm}$;

- Perimeter of shinbone: $9-10 \mathrm{~cm}$.

\section{At ewes:}

- Height at withers: 67-69 cm;

- Height at rump: 67-69 cm;

- Length of body: $68-70 \mathrm{~cm}$;

- Length of rump: $25-27 \mathrm{~cm}$;

- Width at shoulders: $24-26 \mathrm{~cm}$;

- Width at cox-femoral articulations: $26-28 \mathrm{~cm}$;

- Depth of thorax: 30-32 cm;

- Width of thorax: $29-31 \mathrm{~cm}$;

- Perimeter of thorax: 91-93 cm;

- Perimeter of shinbone: $8-9 \mathrm{~cm}$.

\subsubsection{Morph-productive indicators}

- Body weight of adult: - at rams: $95-110 \mathrm{~kg}$; - at ewes: $60-65 \mathrm{~kg}$.

- Weight at birth: 3,5-4,0 kg;

- Weight at weaning: 22-24 kg (75-80 days);

- Weight at 5 months: - males: 40-42 kg; - females: $36-38 \mathrm{~kg}$.

- Average daily gain at fattening: 280-300 g/head;

- slaughtering output: 45-48\%;

- quality carcasses from E, U and R classes;

- meat without specific taste and smell;

- weight of wool coverage: -rams: 4,0-5,0 kg; -ewes: 3,0-4,0 kg.

- finesse of fibres: 22-24 microns;

- staple length 7-10 cm;

- yield of wool scouring: 52-54\%.

\subsubsection{Indicators of reproduction:}

- Fecundity: 96-98\%;

- Prolificacy: 126-130\%;

- Average duration of estrum cycle: 17,09 days (213 ewes);

- The season of reproduction is during the whole year with a period of anestry in February. The mating is done during august- September and the lambing is

- During January - February when more than $90 \%$ of ewes give birth.

3.6. Elements of differentiation between Meat Breed of Palas and local sheep breeds

3.6.1. Morphological characters

The body dimensions 


\section{International Journal of Science and Research (IJSR) \\ ISSN (Online): 2319-7064 \\ Index Copernicus Value (2013): 6.14 | Impact Factor (2014): 5.611}

From the 10 dimensions that had been presented and on which the body conformation, the width of shoulders, the width at cox-femoral articulations and the length of body depends are positively correlated to the degree of muscle development in the areas of the back, chest, loins and gigot, on it depending the conformation of the carcasses and categorising them in the quality classes by SEUROP European grid of classification.

In table 4 the average values of these dimensions comparatively at the Meat Breed of Palas besides Merino of Palas are presented.

Table 4: The average values of body dimensions comparatively at the Meat Breed of Palas besides Merino of Palas

\begin{tabular}{|c|c|c|c|c|c|c|c|c|c|}
\hline \multirow{4}{*}{ No. } & \multirow{4}{*}{ Body Dimensions } & \multicolumn{8}{|c|}{ Breed } \\
\hline & & \multicolumn{4}{|c|}{ Meat Breed of Palas } & \multicolumn{4}{|c|}{ Merino of Palas } \\
\hline & & \multicolumn{2}{|c|}{ Rams } & \multicolumn{2}{|l|}{ Ewes } & \multicolumn{2}{|l|}{ Rams } & \multicolumn{2}{|l|}{ Ewes } \\
\hline & & $\mathrm{X} \pm \mathrm{sx}$ & $\mathrm{V} \%$ & $X \pm s x$ & $\mathrm{~V} \%$ & $X \pm s x$ & $\mathrm{~V} \%$ & $\mathrm{X} \pm \mathrm{sx}$ & $\mathrm{V} \%$ \\
\hline 1. & Width at shoulders & $27,24 \pm 0,2973$ & 6,46 & $24,13 \pm 0,1724$ & 4,52 & $23,66 \pm 0,3418$ & 7,50 & $20,44 \pm 0,2083$ & 7,21 \\
\hline 2. & $\begin{array}{l}\text { Width at cox-femoral } \\
\text { articulations }\end{array}$ & $29,19 \pm 0,3229$ & 6,54 & $26,28 \pm 0,1928$ & 4,64 & $24,59 \pm 0,4074$ & 8,60 & $20,66 \pm 0,1887$ & 6,46 \\
\hline 3. & Length of body & $73,59 \pm 0,5770$ & 4,64 & $68,78 \pm 0,4810$ & 4,42 & $75,26 \pm 0,9407$ & 6,49 & $70,42 \pm 0,4151$ & 4,17 \\
\hline
\end{tabular}

In tables 5 and 6 the differentiation of the 3 body dimensions and the significance of differences are presented.

Table 5: Differentiation of the body dimensions at the rams from the Meat Breed of Palas besides Merino of Palas

\begin{tabular}{|c|l|c|c|c|}
\hline \multirow{2}{*}{ No. } & \multirow{2}{*}{ Body Dimensions } & \multicolumn{3}{|c|}{$\begin{array}{c}\text { Differences between Meat Breed } \\
\text { of Palas and Merino of Palas }\end{array}$} \\
\cline { 3 - 5 } & $\pm \mathrm{cm}$ & $\pm \%$ & $\begin{array}{c}\text { Significance of } \\
\text { differences by } \\
\text { Fisher Test }\end{array}$ \\
\hline 1. & Width at shoulders & $+3,58$ & $+15,13$ & $\mathrm{p}<0,001$ \\
\hline 2. & $\begin{array}{l}\text { Width at cox-femoral } \\
\text { articulations }\end{array}$ & $+4,60$ & $+18,71$ & $\mathrm{p}<0,001$ \\
\hline 3. & Length of body & $-1,67$ & $-2,22$ & $\mathrm{p}>0,05$ \\
\hline
\end{tabular}

Table 6: Differentiation of the body dimensions at the ewes from the Meat Breed of Palas besides Merino of Palas

\begin{tabular}{|c|c|c|c|c|}
\hline \multirow{2}{*}{ No. } & \multirow{2}{*}{ Body Dimensions } & \multicolumn{2}{|c|}{$\begin{array}{c}\text { Differences between Meat Breed of } \\
\text { Palas and Merino of Palas }\end{array}$} \\
\cline { 3 - 5 } & $\pm \mathrm{cm}$ & $\pm \%$ & $\begin{array}{c}\text { Significance of } \\
\text { differences by } \\
\text { Fisher Test }\end{array}$ \\
\hline 1. & Width at shoulders & $+3,69$ & $+18,05$ & $\mathrm{p}<0,001$ \\
\hline 2. & $\begin{array}{c}\text { Width at cox-femoral } \\
\text { articulations }\end{array}$ & $+5,62$ & $+27,20$ & $\mathrm{p}<0,001$ \\
\hline 3. & Length of body & $-1,64$ & $-2,38$ & $\mathrm{p}>0,05$ \\
\hline
\end{tabular}

As it results from table 5 the rams of the Meat Breed of Palas had the widths at shoulders and at cox-femoral articulations bigger with 15-19\% besides Merino of Palas, the differences being statistically very significant.

From table 6 it is observed that also the ewes of Meat Breed of Palas had the widths at shoulders and at cox-femoral articulations bigger with $18-27 \%$ besides Merino of Palas breed.

From tables 5 and 6 it is observed that the length of body at the rams and ewes of Meat Breed of Palas is smaller with 2\% comparatively to Merino of Palas, the difference being statistically insignificant.

\section{- Presence or absence of horns}

At the Meat Breed of Palas the absence of horns is fixed genetically, both sexes being with no horns comparatively to Merino of Palas at which $80 \%$ of rams have big horns, strongly spiralled. Also, cca.10\% of ewes has horns with small dimensions.

\subsubsection{The morph-productive on which the meat} production depends

- The body weight of adult:

It is presented in tables 7,8 and 9.

Table 7: The body weight at the ewes of Meat Breed of Palas comparatively to Merino of Palas

\begin{tabular}{|c|c|c|c|c|}
\hline \multirow{2}{*}{ No. } & \multirow{2}{*}{ Breed } & \multicolumn{3}{|c|}{ The body weight $(\mathrm{kg})$} \\
\cline { 3 - 5 } & & $\mathrm{n}$ & $\mathrm{X} \pm \mathrm{sx}$ & $\mathrm{V} \%$ \\
\hline 1. & Meat Breed of Palas & 194 & $60,75 \pm 0,3232$ & 7,41 \\
\hline 2. & Merino of Palas & 169 & $56,49 \pm 0,5849$ & 13,46 \\
\hline
\end{tabular}

Table 8: The body weight at the rams of Meat Breed of Palas comparatively to Merino of Palas

\begin{tabular}{|c|l|c|c|c|}
\hline \multirow{2}{*}{ No. Breed } & \multicolumn{3}{|c|}{ The body weight $(\mathrm{kg})$} \\
\cline { 3 - 5 } & & $\mathrm{n}$ & $\mathrm{X} \pm \mathrm{sx}$ & $\mathrm{V} \%$ \\
\hline 1. & Meat Breed of Palas & 27 & $97,15 \pm 1,8035$ & 9,65 \\
\hline 2. & Merino of Palas & 18 & $89,50 \pm 2,8893$ & 13,70 \\
\hline
\end{tabular}

Table 9: Differentiation of the body weight at ewes and rams depending on breed

\begin{tabular}{|c|c|c|c|c|c|}
\hline \multicolumn{4}{|c|}{ Differences between Meat Breed and Merino of Palas } \\
\hline \multicolumn{3}{|c|}{ Ewes } & \multicolumn{4}{|c|}{ Rams } \\
\hline$\pm \mathrm{kg}$ & $\pm \%$ & $\begin{array}{c}\text { Significance } \\
\text { of differences }\end{array}$ & $\pm \mathrm{kg}$ & $\pm \%$ & $\begin{array}{c}\text { Significance of } \\
\text { differences }\end{array}$ \\
\hline$+4,26$ & 7,54 & $\mathrm{p}<0,001$ & $+7,65$ & $+8,55$ & $\mathrm{p}<0,001$ \\
\hline
\end{tabular}

From the data of tables 7 and 9 it is noted that the ewes of Meat Breed of Palas had the average weight of $60,75 \mathrm{~kg}$, this being bigger than the contemporaries from Merino of Palas breed. The difference of weight in the favour of sheep from Meat Breed of Palas was statistically very significant.

\section{- Weight growth until the age of 5 months}

It is presented in table 10 .

From the data in the tables 8 and 9 resulted the fact that also the rams from the Meat Breed - Palas had after shearing the average weight of $97,15 \mathrm{~kg}$ besides $89,5 \mathrm{~kg}$ at Merino of Palas.

The difference of weight from the two breeds was statistically very significant.

\section{Volume 5 Issue 6, June 2016 www.ijsr.net}




\section{International Journal of Science and Research (IJSR) \\ ISSN (Online): 2319-7064 \\ Index Copernicus Value (2013): 6.14 | Impact Factor (2014): 5.611}

Table 10: Dynamics of growing since birth to the age of 5 months at the male lambs depending on age

\begin{tabular}{|c|c|c|c|c|c|}
\hline \multirow[b]{2}{*}{ Specification } & \multirow[b]{2}{*}{$\begin{array}{l}\text { Unit of } \\
\text { measure }\end{array}$} & \multicolumn{4}{|c|}{ Breed } \\
\hline & & $\begin{array}{c}\text { Meat } \\
\text { Breed } \\
\text { of Palas }\end{array}$ & $\begin{array}{l}\text { Merino } \\
\text { of Palas }\end{array}$ & Tzigaia & Tzurcana \\
\hline Weight at birth & $\mathrm{kg}$ & 3,90 & 3,90 & 4,15 & 3,95 \\
\hline $\begin{array}{l}\text { Weight at } \\
\text { weaning }\end{array}$ & $\mathrm{kg}$ & $\begin{array}{c}22,03 \\
(79)\end{array}$ & $\begin{array}{c}18,86 \\
(79)\end{array}$ & $\begin{array}{c}22,36 \\
(90)\end{array}$ & $\begin{array}{c}17,36 \\
(70)\end{array}$ \\
\hline $\begin{array}{c}\text { Weight at } 5 \\
\text { months }\end{array}$ & $\mathrm{kg}$ & 38,86 & 33,82 & 28,60 & 30,12 \\
\hline $\begin{array}{c}\text { Daily gain } \\
\text { birth-weaning }\end{array}$ & g & 229,50 & 189,40 & 202,30 & 192,00 \\
\hline $\begin{array}{c}\text { Daily gain } \\
\text { birth-5 months }\end{array}$ & $\mathrm{g}$ & 233,10 & 199,50 & 163,00 & 174,50 \\
\hline
\end{tabular}

Note: between parentheses = average age at weaning in days.

In table 11 the differentiation of weight grow until the age of 5 months at the Meat Breed of Palas besides the local sheep breeds is presented
Table 11: The differentiation of weight growth at the Meat Breed of Palas besides other local sheep breeds

\begin{tabular}{|c|c|c|c|c|c|c|c|}
\hline \multirow{3}{*}{ Feature } & \multirow{3}{*}{$\begin{array}{l}\text { Unit of } \\
\text { measure }\end{array}$} & \multicolumn{6}{|c|}{$\begin{array}{c}\text { Differences between Meat Breed of Palas and } \\
\text { other breeds }\end{array}$} \\
\hline & & \multicolumn{2}{|c|}{$\begin{array}{l}\text { Meat Breed vs. } \\
\text { Merino of Palas }\end{array}$} & \multicolumn{2}{|c|}{$\begin{array}{l}\text { Meat Breed vs } \\
\text { Tzigaia }\end{array}$} & \multicolumn{2}{|c|}{$\begin{array}{c}\text { Meat Breed } \\
\text { vs. } \\
\text { Tzurcana }\end{array}$} \\
\hline & & $\pm \mathrm{UM}$ & $\pm \%$ & $\pm \mathrm{UM}$ & $\pm \%$ & $\begin{array}{c} \pm \\
\mathrm{UM}\end{array}$ & $\pm \%$ \\
\hline $\begin{array}{l}\text { Weight at } \\
5 \text { months }\end{array}$ & $\mathrm{kg}$ & $+5,04$ & $+14,90$ & $+10,26$ & $\begin{array}{r}+ \\
35,60 \\
\end{array}$ & $\begin{array}{c}+ \\
8,74 \\
\end{array}$ & $\stackrel{+}{+}$ \\
\hline $\begin{array}{l}\text { Daily gain } \\
\text { since birth } \\
\text { to } 5 \\
\text { months }\end{array}$ & $\mathrm{g}$ & $+33,60$ & $+16,84$ & $+70,10$ & $\stackrel{+}{+}$ & $\begin{array}{c}+ \\
58,30\end{array}$ & $\begin{array}{c}+ \\
33,35\end{array}$ \\
\hline
\end{tabular}

As it can be noted in table 11, the Meat Breed of Palas is clearly different regarding the living weight at 5 months besides all local breeds, the male lambs of this age being heavier with $14,90 \%$ than their contemporaries of Merino of Palas and much heavier than the lambs of Tzigaia and Tzurcana at the same age (with $35,6 \%$ and respectively $29,02 \%$ ). The average daily increasing rate since birth to 5 months was also bigger at the Meat Breed of Palas than at the local sheep breeds.

\section{- Slaughtering output}

The slaughtering output at the Meat Breed of Palas comparatively to other breeds is presented in table 12 .

Table 12: The slaughtering output comparatively on breeds

\begin{tabular}{|l|c|c|c|c|c|}
\hline \multirow{2}{*}{ Specification } & \multirow{2}{*}{ Unit of measure } & \multicolumn{4}{c|}{ Breed } \\
\cline { 3 - 6 } & & Meat Breed of Palas & Merino of Palas & Tzigaia & Tzurcana \\
\cline { 3 - 6 } & & $\mathrm{X} \pm \mathrm{sX}$ & $\mathrm{X} \pm \mathrm{sx}$ & $\mathrm{X} \pm \mathrm{sx}$ & $\mathrm{X} \pm \mathrm{sX}$ \\
\hline Living weight before slaughtering & $\mathrm{g}$ & $39261,1 \pm 958$ & $39555,6 \pm 1402$ & $38925 \pm 931$ & $35333 \pm 2204,8$ \\
\hline Empty living weight & $\mathrm{g}$ & $33338,9 \pm 967,7$ & $34711,1 \pm 1380$ & $32925 \pm 1177,8$ & $31500 \pm 1892,9$ \\
\hline Weight of cooled carcass & $\mathrm{g}$ & $18982,2 \pm 967,7$ & $17642,8 \pm 809,5$ & $17402,5 \pm 694$ & $15276,7 \pm 1266,2$ \\
\hline Output 1 & $\%$ & 48,35 & 44,60 & 44,70 & 43,20 \\
\hline Output 2 & $\%$ & 56,94 & 50,83 & 52,80 & 48,50 \\
\hline
\end{tabular}

In table 13 the differentiations of the slaughtering outputs of the Meat Breed and the breeds of Merino of Palas, Tzigaia and Tzurcana are presented.

Table 13: Differentiation of the slaughtering output at the Meat Breed-Palas besides other breeds

\begin{tabular}{|l|c|c|c|}
\hline \multirow{2}{*}{ Specification } & \multicolumn{3}{|c|}{ Differentiation of the slaughtering output \pm} \\
per cent points \\
\cline { 2 - 4 } & $\begin{array}{c}\text { Meat Breed } \\
\text { besides Merino }\end{array}$ & $\begin{array}{c}\text { Meat Breed } \\
\text { besides Tzigaia }\end{array}$ & $\begin{array}{c}\text { Meat Breed } \\
\text { besides Tzurcana }\end{array}$ \\
\hline Output 1 & $+3,75$ & $+3,65$ & $+5,15$ \\
\hline Output 2 & $+6,11$ & $+4,14$ & $+8,44$ \\
\hline
\end{tabular}

As it can be noted from tables 12 and 13 at Meat Breed Palas the output 1 at slaughtering was of $48,35 \%$, bigger with
3,75 per cent points besides Merino of Palas and with 3,65 points $-5,15$ points besides Tzigaia and Tzurcana breeds.

Regarding the output 2 at slaughtering the differences were more accentuated, they being of 6,11 per cent points between the Meat Breed and Merino of Palas and 4,14 points - 8,44 points between the Meat Breed and Tzgaia, respectively Tzurcana.

The slaughtering output of the lambs from the Meat Breed Palas round the living weight of $40 \mathrm{~kg}$ is similar to the values registered by the lambs from the same weight class of the Ile de France breed and other meat breeds.

\section{- Features on which the quality of the carcass depends}

Their values are presented in table 14 . 


\section{International Journal of Science and Research (IJSR) \\ ISSN (Online): 2319-7064 \\ Index Copernicus Value (2013): 6.14 | Impact Factor (2014): 5.611}

Table 14: Dimensions of carcasses at the lambs from the Meat Breed - Palas comparatively to other breeds

\begin{tabular}{|l|c|c|c|c|}
\hline \multirow{2}{*}{\begin{tabular}{c}
\multirow{2}{*}{$\begin{array}{c}\text { Dimension } \\
(\mathrm{cm})\end{array}$} \\
\cline { 2 - 5 }
\end{tabular}} & Meat Breed & Merino of Palas & Tzigaia & Tzurcana \\
\cline { 2 - 5 } & $\mathrm{X} \pm \mathrm{sx}$ & $\mathrm{X} \pm \mathrm{sx}$ & $\mathrm{X} \pm \mathrm{sx}$ & $\mathrm{X} \pm \mathrm{sx}$ \\
\hline Width at cox-femoral articulations (G) & $23,83 \pm 0,4409$ & $20,50 \pm 0,2887$ & $20,13 \pm 0,3146$ & $18,83 \pm 0,6009$ \\
\hline Width of thorax & $27,67 \pm 0,4409$ & $23,44 \pm 0,5740$ & $25,50 \pm 0,6124$ & $23,00 \pm 0,2887$ \\
\hline Width at scapula - humeral articulations & $22,67 \pm 0,6009$ & $20,06 \pm 0,3379$ & $19,50 \pm 0,2041$ & $18,80 \pm 0,3333$ \\
\hline Depth of thorax & $29,83 \pm 0,6009$ & $28,22 \pm 0,7597$ & $27,38 \pm 0,3146$ & $30,17 \pm 0,6667$ \\
\hline Length of carcass (K) & $64,50 \pm 0,5000$ & $63,56 \pm 0,4747$ & $63,13 \pm 1,1968$ & $63,00 \pm 0,500$ \\
\hline Length of gigot (F) & $24,83 \pm 0,4410$ & $26,67 \pm 0,6292$ & $25,88 \pm 0,4269$ & $28,33 \pm 1,0138$ \\
\hline Perimeter of gigot & $47,83 \pm 0,4410$ & $41,33 \pm 0,6455$ & $43,63 \pm 0,8985$ & $41,67 \pm 0,8333$ \\
\hline Indicator of carcass' compactness (IC) & 0,37 & 0,32 & 0,32 & 0,30 \\
\hline Indicator of the compactness of the gigot (IJ) & 0,96 & 0,77 & 0,78 & 0,66 \\
\hline
\end{tabular}

Differentiation between certain dimensions on which the quality of carcass depends at the Meat Breed and other breeds is being presented in table 15 .

Table 15: Differentiation between Meat Breed and other sheep breeds regarding certain dimensions

\begin{tabular}{|c|c|c|c|c|c|c|c|}
\hline \multirow[t]{3}{*}{ Dimension } & \multirow{3}{*}{$\begin{array}{l}\text { Unit of } \\
\text { measure }\end{array}$} & \multicolumn{6}{|c|}{ Differences between Meat Breed and other sheep breeds } \\
\hline & & \multicolumn{2}{|c|}{$\begin{array}{l}\text { Meat Breed and } \\
\text { Merino of Palas }\end{array}$} & \multicolumn{2}{|c|}{ Meat Breed and Tzigaia } & \multicolumn{2}{|c|}{ Meat Breed and Tzurcana } \\
\hline & & $\pm \mathrm{UM}$ & $\pm \%$ & $\pm \mathrm{UM}$ & $\pm \%$ & $\pm \mathrm{UM}$ & $\pm \%$ \\
\hline 0 & 1 & 2 & 3 & 4 & 5 & 6 & 7 \\
\hline Width at cox-femoral articulations & $\mathrm{cm}$ & $+3,33$ & $+16,24$ & $+3,70$ & $+18,38$ & $+5,00$ & $+26,55$ \\
\hline 0 & 1 & 2 & 3 & 4 & 5 & 6 & 7 \\
\hline Length of gigot & $\mathrm{cm}$ & $-1,84$ & $-6,90$ & $-1,05$ & $-4,06$ & $-3,50$ & $-12,35$ \\
\hline Perimeter of gigot & $\mathrm{cm}$ & $+6,50$ & $+15,73$ & $+4,20$ & $+9,63$ & $+6,16$ & $+14,78$ \\
\hline Indicator of carcass' compactness (IC) & - & $+0,05$ & $+15,63$ & $+0,05$ & $+15,63$ & $+0,07$ & $+23,30$ \\
\hline Indicator of the compactness of the gigot (IJ) & - & $+0,19$ & $+24,68$ & $+0,18$ & $+23,08$ & $+0,30$ & $+45,50$ \\
\hline
\end{tabular}

As it results from tables 14 and 15 , the carcasses of the lambs of Meat Breed - Palas, having a length approximately equal to the Merinos de Palas, Tzigaia and Tzurcana breeds $(63,0-64,5 \mathrm{~cm})$ were wider with $16-27 \%$ and had the gigot shorter with $4-12 \%$ than the local breeds. Also, the carcasses of lambs from Meat Breed - Palas, were more compact than the carcasses of local breeds, the compactness indicator having its values higher with $16-23 \%$, and the indicator of the compactness of the gigot was higher with $23-46 \%$ than Merino, Tzigaia and Tzurcana breed.
The researches of various authors established the existence of certain close correlations between the surface of the section of Longissimus Dorsi muscle (at the level of the last rib) and the section of thigh (in the middle of femur perpendicularly on its axe) and developing the muscles of gigot, back, loins and the whole carcass

- The surface of the section of Longissismus Dorsi muscle In table 16 the surface of the section of Longissismus Dorsi muscle at the Meat Breed - Palas comparatively to other breeds is presented.

Table 16 The surface of the section of Longissismus Dorsi muscle at the Meat Breed - Palas besides local breeds

\begin{tabular}{|c|c|c|c|c|c|c|c|}
\hline \multirow{3}{*}{ Breed } & \multirow{3}{*}{$\begin{array}{l}\text { The surface of the } \\
\text { section of } \\
\begin{array}{c}\text { Longissismus Dorsi } \\
\text { muscle }\left(\mathrm{cm}^{2}\right)\end{array} \\
\mathrm{X} \pm \mathrm{sx}\end{array}$} & \multicolumn{6}{|c|}{ Differences between breeds } \\
\hline & & \multicolumn{2}{|c|}{ Meat Breed vs. Merino } & \multicolumn{2}{|c|}{ Meat Breed vs. Tzigaia } & \multicolumn{2}{|c|}{ Meat Breed vs. Tzurcana } \\
\hline & & $\pm \mathrm{cm}^{2}$ & $\pm \%$ & $\pm \mathrm{cm}^{2}$ & $\pm \%$ & $\pm \mathrm{cm}^{2}$ & $\pm \%$ \\
\hline Meat Breed - Palas & $17,70 \pm 0,9088$ & \multirow{4}{*}{$+2,59$} & \multirow{4}{*}{$+17,14$} & \multirow{4}{*}{$+4,29$} & \multirow{4}{*}{$+32,00$} & \multirow{4}{*}{$+5,68$} & \multirow{4}{*}{$+47,30$} \\
\hline Merino of Palas & $15,11 \pm 0,4898$ & & & & & & \\
\hline Tzigaia & $13,41 \pm 0,4951$ & & & & & & \\
\hline Tzurcana & $12,02 \pm 1,2375$ & & & & & & \\
\hline
\end{tabular}

As it is noted from table 16 there are big differences between Meat Breed- Palas and the local breeds regarding the surface of the muscle eye. It was bigger at Meat Breed -Palas with 17- $47 \%$ besides Merinos, Țigaie and Țurcan breeds.

\section{- Surface of thigh section}

In table 17 the surface of the thigh section at the carcasses of the lambs from the Meat Breed - Palas comparatively to the local ovine breeds is presented. 


\section{International Journal of Science and Research (IJSR) \\ ISSN (Online): 2319-7064 \\ Index Copernicus Value (2013): 6.14 $\mid$ Impact Factor (2014): 5.611}

Table 17: The surfaces of the thigh section at the carcasses from the fattened lambs of Meat Breed-Palas comparatively to other local breeds

\begin{tabular}{|c|c|c|c|c|c|c|c|}
\hline \multirow{3}{*}{ Breeds } & \multirow{3}{*}{$\begin{array}{l}\begin{array}{l}\text { Surface of thigh } \\
\text { section }\left(\mathrm{cm}^{2}\right)\end{array} \\
\mathrm{X} \pm \mathrm{sx}\end{array}$} & \multicolumn{6}{|c|}{ Differences between breeds } \\
\hline & & \multicolumn{2}{|c|}{ Meat Breed vs. Merino } & \multicolumn{2}{|c|}{ Meat Breed vs. Tzigaia } & \multicolumn{2}{|c|}{ Meat Breed vs. Tzurcana } \\
\hline & & $\pm \mathrm{cm}^{2}$ & $\pm \%$ & $\pm \mathrm{cm}^{2}$ & $\pm \%$ & $\pm \mathrm{cm}^{2}$ & $\pm \%$ \\
\hline Meat Breed -Palas & $146,75 \pm 4,8522$ & \multirow{4}{*}{$+30,68$} & \multirow{4}{*}{$+26,43$} & \multirow{4}{*}{$+37,00$} & \multirow{4}{*}{$+33,71$} & \multirow{4}{*}{$+43,35$} & \multirow{4}{*}{$+41,92$} \\
\hline Merino of Palas & $116,07 \pm 4,9384$ & & & & & & \\
\hline Tzigaia & $109,75 \pm 5,6199$ & & & & & & \\
\hline Tzurcana & $103,40 \pm 6,0867$ & & & & & & \\
\hline
\end{tabular}

As it results from table 17, Meat Breed -Palas is clearly different from Merino of Palas, Tzigaia and Tzurcana regarding the size of the surface of the thigh section. It was bigger at Meat Breed -Palas with 26-43\% than the local breeds.
- The tissue structure of the carcass

The tissue structure of the carcass is presented in table 18

Table 18 Tissue structure of the carcass at Meat Breed - Palas comparatively to Merino de Palas, Tzigaia and Tzurcana

\begin{tabular}{|c|c|c|c|c|c|c|c|}
\hline \multirow{2}{*}{ Specification } & \multicolumn{3}{|c|}{ Tissue structure (\%) } & \multicolumn{2}{c|}{ Differences between breeds \pm per cent points } \\
\cline { 2 - 8 } & $\begin{array}{c}\text { Meat Breed } \\
\text {-Palas }\end{array}$ & $\begin{array}{c}\text { Merino of } \\
\text { Palas }\end{array}$ & Tzigaia & Tzurcana & $\begin{array}{c}\text { Meat Breed } \\
\text { besides Merino }\end{array}$ & $\begin{array}{c}\text { Meat Breed } \\
\text { besides Tzigaia }\end{array}$ & $\begin{array}{c}\text { Meat Breed besides } \\
\text { Tzurcana }\end{array}$ \\
\hline 0 & 1 & 2 & 3 & 4 & 5 & 6 & 7 \\
\hline $\begin{array}{c}\text { Total semi-carcass, } \\
\text { out of which: }\end{array}$ & 100,00 & 100,00 & 100,00 & 100,00 & - & - & - \\
\hline 0 & 1 & 2 & 3 & 4 & 5 & 6 & 7 \\
\hline Muscles & 61,30 & 57,42 & 51,56 & 57,00 & $+3,88$ & $+9,74$ & $+4,30$ \\
\hline Fat & 17,49 & 19,25 & 24,22 & 17,42 & $-1,76$ & $-6,73$ & $+0,07$ \\
\hline Bones & 20,96 & 23,14 & 24,06 & 25,37 & $-2,18$ & $-3,10$ & $-4,41$ \\
\hline $\begin{array}{c}\text { Proportion of } \\
\text { muscle/bones }\end{array}$ & $2,92 / 1$ & $2,48 / 1$ & $2,14 / 1$ & $2,25 / 1$ & - & - & - \\
\hline
\end{tabular}

As it results from the data in table 18, Meat Breed -Palas is clearly different from the other local breeds regarding the structure of the carcass. The quantity of muscle in the carcass was bigger with 3,88 per cent points than Merino of Palas, bigger with 9,74 per cent points than Tzigaia and with 4,3 per cent points bigger than Tzurcana. Also, at Meat Breed Palas, the quantity of bones from the carcass was smaller with 2,18 per cent points than Merino of Palas, with 3,10 per cent points than Tzigaia and with 4,41 per cent points than Tzurcana.
The proportion of muscles /bones in the carcass at Meat Breed -Palas was of 2,92/1 besides 2,48/1 at Merino, of $2,14 / 1$ at Tzigaia and of 2,25/1 at Tzurcana.

- Classification of carcasses by SEUROP grid

In table 19 the classification of the carcasses on quality classes by European classification grid is presented.

Table 19: Classification of carcasses by SEUROP grid

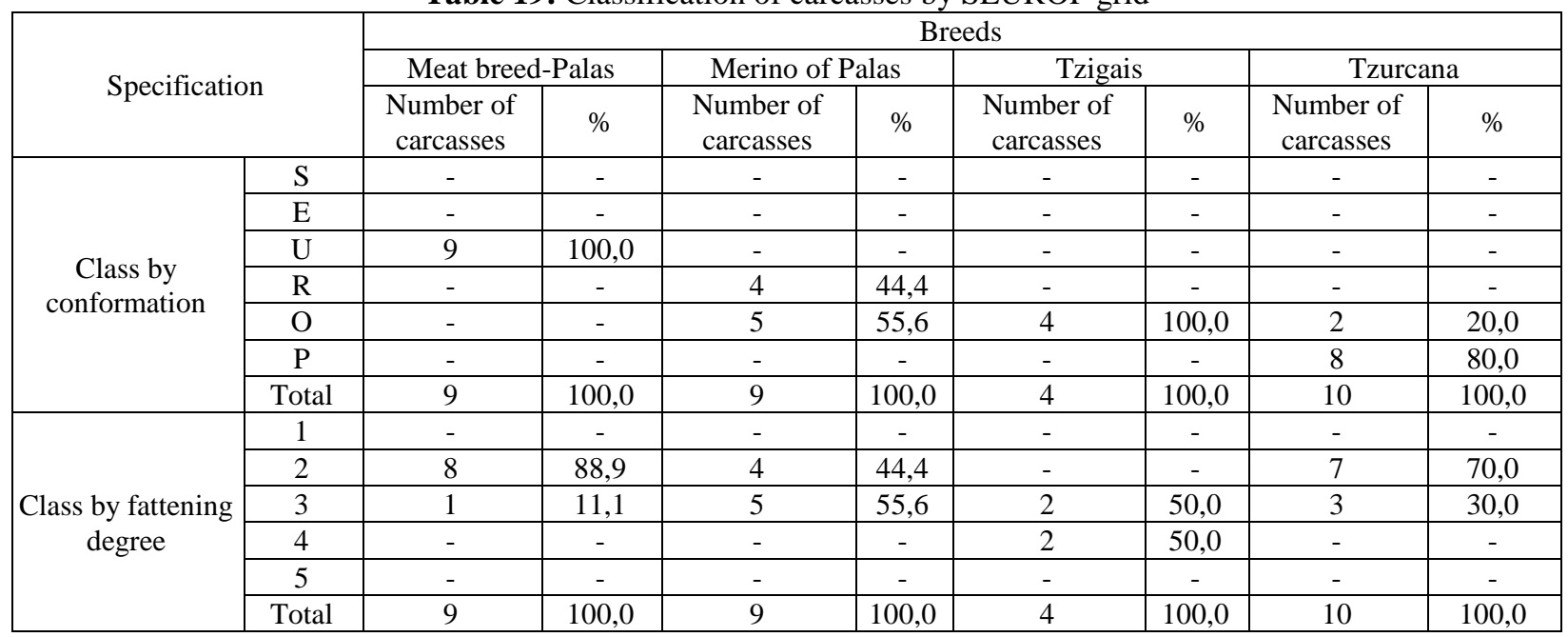

From the data presented in the table it results that at Meat Breed -Palas all carcasses were included by conformation in U class (very good carcasses), and by the fattening state in the $2^{\text {nd }}$ and $3^{\text {rd }}$ classes (thin and mid fat carcasses, the most required on market); at Merino of Palas breed, the carcasses were included in the proportion of cca.44\% in R class (good carcasses) and $56 \%$ in $\mathrm{O}$ class (satisfactory), and by the fattening state in the $2^{\text {nd }}$ and $3^{\text {rd }}$ classes (thin and mid fat

Volume 5 Issue 6, June 2016 www.ijsr.net 
carcasses); at Tzigaia were included in O class (satisfactory), and by the degree of fattening $50 \%$ in $3^{\text {rd }}$ class (mid fat) and $50 \%$ in $4^{\text {th }}$ class (fat carcasses, unrequired on market); at Tzurcana $20 \%$ of carcasses were included in O class (satisfactory), and $80 \%$ in $\mathrm{P}$ class (mediocre carcasses, unrequired on market), and by the degree of fattening the carcasses were included in the $2^{\text {nd }}$ and $3^{\text {rd }}$ classes.

\section{Conclusions}

In conclusion we can say that Meat Breed is clearly different from Merino of Palas and other local breeds as follows:

The breed has the brevi-morph to middle-morph body conformation which is characteristic to the meat breeds. The body is wide and deep, long enough, being well covered with muscles. The dimensions of length and width are significantly bigger than Merino of Palas. The gigot are distended, convex and well covered with muscles, being different from Merino which has the gigot straight or a little concave.

The body conformation at Meat Breed -Palas is similar to other meat breeds from EU.

The weight increase of the lambs until 5 months is significantly bigger at the Meat Breed - Palas than the other local sheep breeds. Also, the slaughtering output and the quality indicators of the carcasses are entirely superior besides the local sheep breeds.

\section{References}

[1] N.Ciolcă, S. Timariu, Al. Ursescu, Aida Avram, Sultana Cuşa - Aptitudes for meat production at the breeds and varieties of sheep being bred in Romania. Scientific works of SCCCO Palas- Constanţa, vol.I., 1972. Redaction of Agricultural Magazines, Bucharest.

[2] C. Drăgănescu -Animals Improvement. Ceres Publishing House, Bucharest, 1979.

[3] E.Laville et.al. - La conformation boucherre des agneaux. Etude d'apres la variabilité génétique entre races. INRA Prod.Anim.15 (1), pp 53-66, 2002.

\section{Author Profile}

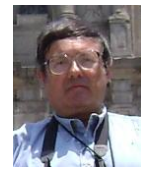

Dr. Petru -Gabriel Vicovan - Scientific researcher $1^{\text {st }}$ degree, since 1998 Doctor in Animal Breeding, Speciality - Animal. Genetics and Breeding. Profesional experience: 44 years in the field of research scientific at Research and Development Institute for Sheep and Goats Breeding Palas - Constanţa, Romania. Current job and position: scientific director at Research and Development Institute for Sheep and Goats Breeding Palas Constanţa, Romania. During the whole period he coordinated many projects like: Genetic polymorphism of blood and milk protein in sheep in relation to adaptation to the environment; Creating a new lines breed of sheep and goats; Researches for development of special hybrids for meat in sheep and goats. He was published 65 research papers and created a breed sheep - for meat - Meat breed Palas. 